\title{
Patent ductus arteriosus-related endocarditis: not just a theoretical risk
}

\author{
Umar Farooq Mahmood, Saravanan Durairaj
}

Paediatric Cardiology, Glenfield Hospital East Midlands Congenital Heart Centre, Leicester, UK

\section{Correspondence to} Dr Umar Faroog Mahmood; umar.mahmood@nhs.net

Accepted 29 May 2021
Check for updates

(C) BMJ Publishing Group Limited 2021. No commercial re-use. See rights and permissions. Published by BMJ.

To cite: Mahmood UF,
Durairaj S. BMJ Case
Rep 2021;14:e241201.
doi:10.1136/bcr-2020-
241201

\section{DESCRIPTION}

We present a 3-year-old girl with an asymptomatic patent ductus arteriosus (PDA) awaiting an elective transcatheter device closure. She presented with a 2 -week history of high-grade fever $\left(40^{\circ} \mathrm{C}\right)$. There was associated abdominal pain and reduced appetite. There was no history of respiratory symptoms or Kawasaki disease. She was initially treated for tonsillitis with penicillin V after a telephone consultation. Due to no improvement, she was seen in her urgent care centre and advised to isolate. She continued to have high temperatures and had a number of telephone consultations and urgent care visits. Four months earlier, she had an uncomplicated dental extraction because of dental abscesses that required courses of antibiotics.

In the hospital, she was treated for presumed sepsis and it was felt that this could be paediatric multisystem inflammatory syndrome temporally associated with COVID-19. Her initial C-reactive protein was $154 \mathrm{mg} / \mathrm{L}$, White cell count was $16.9 \times 10^{9} / \mathrm{L}$ with a neutrophil count of $12.9 \times 10^{9} / \mathrm{L}$. She was started on intravenous ceftriaxone and discussed with our department. Her COVID-19 swab was negative but her blood cultures grew Staphylococcus aureus. Following the positive blood culture, intravenous vancomycin was added. Her antibiotics were changed to intravenous flucloxacillin once her sensitivity report had returned. An echocardiogram performed locally showed no vegetations but her PDA was difficult to visualise. There was uncertainty about coronary dilatation, hence she was brought to our unit for a detailed echocardiogram.

The echocardiogram demonstrated a vegetation in the main pulmonary artery (figure 1) and normal coronaries. She was admitted to our centre and also had a CT pulmonary angiogram. This showed multiple thick-walled cavitating lesions of up to $15 \mathrm{~mm}$ in the right upper and lower lobes of the lung (figure 2). There was also a right middle lobe collapse and a moderate right pleural effusion with associated passive atelectasis.

Upon admission to our unit, she had already completed 3 days of intravenous flucloxacillin. Her C-reactive Protein was $68 \mathrm{mg} / \mathrm{L}$. We continued intravenous flucloxacillin. Her subsequent blood cultures have been negative. Her C -reactive protein normalised by day 16 of intravenous flucloxacillin. She completed 6-week course of antibiotics. Echocardiogram remained unchanged and her repeat CT post treatment demonstrated a much improved appearance of her lungs. She then underwent surgical ligation of PDA.

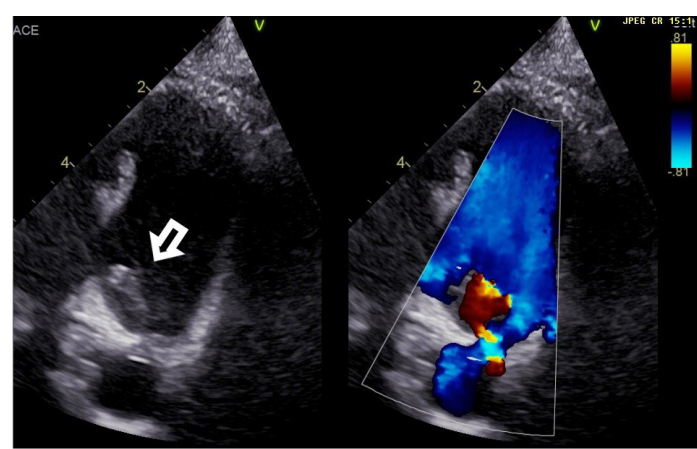

Figure 1 Echocardiogram: Vegetation seen in the main pulmonary artery.

It is standard practice to counsel patients with congenital heart disease about the risk of infective endocarditis and advise them to have regular dental checks to reduce their risk. The child's parents have always been encouraged to see the dentist on a regular basis. She had recently had a dental procedure and it is unfortunate that she went on to develop endocarditis. We firmly believe that the lack of dental appointments available during the pandemic contributed to her presentation.

Endocarditis in the young has dramatically declined in recent times due to better dental and medical care in congenital heart disease. ${ }^{1}$ PDArelated endocarditis is a rare occurrence ${ }^{2}$ but remains a risk factor for infective endocarditis typically in developing countries. ${ }^{3-5}$ PDA is still not considered as an indication for infective endocarditis antibiotic prophylaxis. Surgical ligation

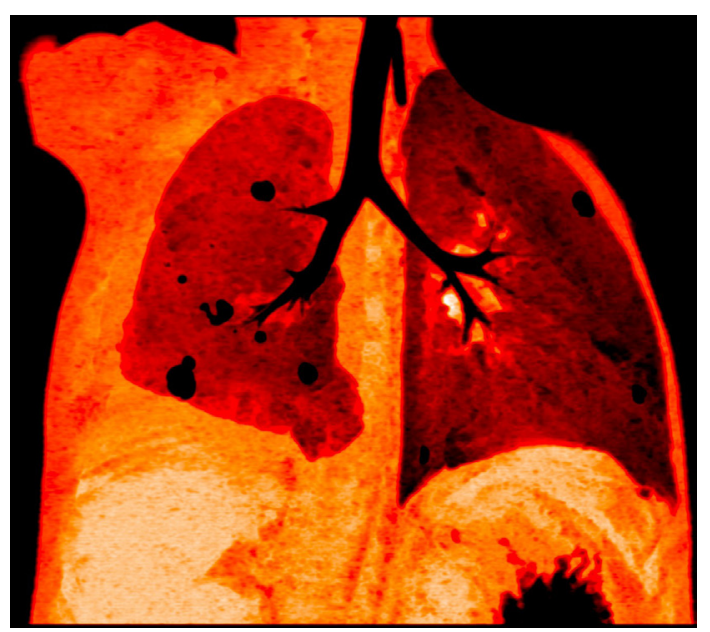

Figure 2 CT: Demonstrating cavitations in the right lung. 
and transcatheter device closure of a PDA are common and well-documented procedures. There remains some controversy regarding closing haemodynamic insignificant PDA. ${ }^{1}$

Our child had a small PDA that unfortunately was anything other than innocent. We highlight the importance of good dental hygiene, high suspicion of endocarditis in the child with an underlying congenital heart defect and the need for face-to-face consultations.

\section{Learning points}

Today's climate fosters a high level of suspicion of atypical presentations related to COVID-19. We encourage clinicians not to get sidetracked and to maintain an open mind about pre-COVID-19 differential diagnoses.

- Dental hygiene and regular dental checks are especially crucial in those with congenital heart disease.

- Telephone consultations can be very useful in the community setting. This case highlights their possible limitations.
Contributors UFM: Wrote the article and performed the literature review. SD: Patient consultant who is in charge of the patient's overall care. I oversaw and helped with the editing of this article and providing guidance on diagnostic imaging.

Funding The authors have not declared a specific grant for this research from any funding agency in the public, commercial or not-for-profit sectors.

Competing interests None declared.

Patient consent for publication Obtained.

Provenance and peer review Not commissioned; externally peer reviewed.

\section{REFERENCES}

1 Rosenthal LB, Feja KN, Levasseur SM, et al. The changing epidemiology of pediatric endocarditis at a children's Hospital over seven decades. Pediatr Cardiol 2010;31:813-20.

2 Bilge M, Üner A, Özeren A, et al. Pulmonary endarteritis and subsequent embolization to the lung as a complication of a patent ductus arteriosus--a case report. Angiology 2004;55:99-102.

3 Sadiq M, Latif F, Ur-Rehman A. Analysis of infective endarteritis in patent ductus arteriosus. Am J Cardiol 2004;93:513-5.

4 Cardiology ESo. Infective endocarditis (guidelines on prevention, diagnosis and treatment of) ESC clinical practice guidelines, 2009.

5 Rushani D, Kaufman JS, Ionescu-Ittu R, et al. Infective endocarditis in children with congenital heart disease: cumulative incidence and predictors. Circulation 2013;128:1412-9

Copyright 2021 BMJ Publishing Group. All rights reserved. For permission to reuse any of this content visit

https://www.bmj.com/company/products-services/rights-and-licensing/permissions/

BMJ Case Report Fellows may re-use this article for personal use and teaching without any further permission.

Become a Fellow of BMJ Case Reports today and you can:

- Submit as many cases as you like

- Enjoy fast sympathetic peer review and rapid publication of accepted articles

- Access all the published articles

- Re-use any of the published material for personal use and teaching without further permission

Customer Service

If you have any further queries about your subscription, please contact our customer services team on +44 (0) 2071111105 or via email at support@bmj.com.

Visit casereports.bmj.com for more articles like this and to become a Fellow 